\title{
Religious song as a facilitator of prosocial behavior
}

Batara, Jame Bryan L.

University of San Carlos, Philippines (jamebatara5@gmail.com)

Accepted: 10 September 2015

\section{类此}

ISSN: 2243-7681 Online ISSN: 2243-769X

OPEN ACCESS

\section{Abstract}

Religion plays an important role in human life. In a recent review, religiosity has been associated with prosocial behavior; although consistent, the association was weak (Saroglou, 2013). To understand religious prosociality, varying theoretical contentions were offered (Preston, Salomon, \& Ritter, 2013). The present study tested Supernatural Monitoring Hypothesis and sought to identify the role of the thought of a watching God in a religious individual's prosocial behavior. With this aim, an experiment was conducted with two groups of participants wherein the experimental group was primed with the thought of a watching God through a song translation. Results of independent samples t-test showed that religious participants who were primed offered more time for a volunteer work compared to those who were not primed. Implications of this study point to the role of the thought of a watching God in prosocial behavior.

Keywords: religiosity; religious priming; supernatural monitoring hypothesis; prosocial behavior 


\section{Religious song as a facilitator of prosocial behavior}

\section{Introduction}

Helping is a core value in religion (Batson, 1990) and people consider religion as part of their lives (Zuckerman, 2005). However, it has just been recent that studies on religion and psychology gets back to its pace (Sedikides, 2010). In this connection, recent review found a weak association between religiosity and prosocial behavior partly because religious prosociality has been more strongly associated to helping the ingroup than the outgroup (Saroglou. 2013). Theories emerged as attempts in explaining the link between religion and prosocial behavior. Interestingly, it has been suggested that activating one's thought of a watching God can increase prosocial behavior (e.g., Shariff \& Norenzayan, 2007). With this, the present study aimed to look into the influence of the thought of a watching God in one's willingness to volunteer.

Religion includes the feelings, thoughts, and processes that arise from the search for the sacred in the presence of a community that prescribes set of religious practices, or an attempt to reach goals that are not necessarily sacred (e.g., belongingness) but are done in the religious context (Hill et al., 2000). There are different definitions about religion such as intrinsic and extrinsic religious orientation (Allport, 1966), religious quest orientation (Batson, 1976), and the establishment of rituals to recognize the power of a higher being (Wulff, 1997). Although there have been debates about the link between religion and prosociality (for review, see Galen 2012), it has been contended that in many ways one's religiosity facilitates prosocial behavior (Saroglou, 2012). In the present study, the focus was on activating one's thought of God and how this thought influenced one's willingness to volunteer.

There have been varied views regarding the concepts of religiosity and spirituality. Spirituality is viewed as a transcendental experience (LaPierre, 1994) which emphasizes concern for human potential (Spilka, 1993 as cited in Hill et al., 2000). Religion has been viewed as institutionalized in structure, which in turn limits a person's freedom (Pargament, 1997; Pargament, 1999; Zinnbauer, Pargament, \& Scott, 1999). Religion has been commonly referred as a set of rules and practices with respect to the group's faith whereas spirituality is one's relationship with God or the divine (Zinnbauer et al., 1997). A common misconception is the idea that religion is bad whereas spirituality is good (Zinnbauer et al., 1999), and that spirituality appears to be viewed as more personal and private (Spilka \& McIntosh, 1996, as cited in Hill et al., 2000).

Because different scholars attached somehow different meanings to religiosity and spirituality, it has come to a point that these two constructs are studied and viewed separately. Amid the debates and misconceptions regarding the concepts of religiosity and spirituality, the common point is that these two overlapping concepts recognize the presence of practices (practices in spirituality are often private) related to the search for the sacred (Hill et al., 2000). It may be viewed that religion may serve as a repertoire of different spirituality expressed and done in the context of the community. Spirituality then, in this sense, is a private practice of the search for the sacred. In the present study, however, the focus is on the influence of activating one's thought of a watching God in willingness to help.

On the other side, prosocial behavior refers to general helping behavior that serves to benefit others indirectly or directly (Preston et al., 2013). A bulk of studies already have found consistent link between religiosity and prosocial behaviors (for a recent review, see Preston, Ritter, \& Hernandez, 2010 and Saroglou, 2013). For example, religiosity facilitates everyday minimal-cost helping (Batara, 2015), cooperation and generosity (Ahmed, 2009), and even philanthropy (Lincoln, Morrissey, \& Mundey, 2008). Religious individuals have also been stereotyped as helpful, generous, compassionate, and empathic (Lewis, MacGregor, \& Putnam, 2013; Saroglou, Pichon, Trompette, Verschueren, \& Dernelle, 2005; Underwood, 2002). Saroglou (2012) also found that in the data of European Social Survey (2006-2007), religious people also were mostly helping 
professionals in the fields of health, teaching, and personal care. Together, these suggest that religiosity contributes to increased prosocial behavior.

In addition, theories explaining this consistent link have also emerged. For example, religious prosociality has been viewed as a result of the cohesive community promoting religious teachings, respect for the religious, and shared religious beliefs and practices (Graham \& Haidt, 2010). Graham and Haidt (2010) contended that the three foundations of religion namely ingroup/loyalty, authority/respect, and purity/sanctity serve to enhance the religious group's cohesion; thus, this facilitates helping towards those members who need help. Another perspective is that religious participation and its corresponding religious prosocial behaviors serve as a means of showing commitment to one's group (Alcorta \& Sosis, 2005). They further argued that one's religion is not only limited to cognition but has also social functions (Alcorta \& Sosis, 2005; Purzycki \& Sosis, 2009). Recently, religious prosociality has been viewed as an extension from biological kin to psychological kin concerned with the welfare of those belonging in the religious group (Crespi \& Summers, 2014). More interestingly, Crespi and Summers (2014) suggest that religion's adaptive function rests on the idea that one's belief in God is translated to serving those in one's religious circle. Lastly, the thought that one is being watched by God is also said to facilitate prosocial behavior. This thought of an omnipresent God refers to supernatural monitoring hypothesis (Norenzayan \& Shariff, 2008; Norenzayan et al., 2014; Shariff \& Norenzayan, 2007). In the present study, this hypothesis was tested through an experiment.

In an evolutionary perspective, the thought that God is watching an individual's thoughts and actions contribute to cooperation in groups (Bering \& Johnson, 2005; Johnson \& Bering, 2006; Shariff, Norenzayan, \& Henrich, 2009). Hence, thinking about a supernatural monitoring agent activates an individual's reputational concern which in turn influences tendency to exhibit prosocial behavior (Norenzayan \& Shariff, 2008; see also Piazza, Bering, \& Ingram, 2011). For example, lack of anonymity and increased feeling of being monitored, which activate reputational concern, facilitate prosocial behavior (Bering, McLeod, \& Shackelford, 2005). Moreover, the ability to think about what these supernatural agents think (i.e., theory of mind) facilitate the concern for engaging in prosocial behavior in compliance with what the supernatural agent expects the individual to behave (Norenzayan et al., 2014). Thus, in general, thinking about God serves as a "social surveillance" (p. 301, Gervais \& Norenzayan, 2012) in which a religious individual needs to comply so as to avoid punishment from both the supernatural agent and the religious community (Johnson \& Bering, 2006). Thus, activating one's thought of a watching God may facilitate prosocial behavior. In the present study, priming through a song translation was used to activate the thought of a watching God.

In the recent years, studies of religious priming and its influence in prosocial behavior have been continually conducted. Most of these priming studies are either through word primes or context primes. In terms of context primes, it has been found that prosocial behavior is more pronounced in the presence of religious structures. For example, individuals were more willing to help a person in front of a church than of a gymnasium (Pichon \& Saroglou, 2009). Imagining that one is in a synagogue than in a fitness or music center also facilitated more time allotted for their mobile phones to be borrowed by another individual in the same context (Ruffle \& Sosis, 2010). Individuals inside a religious structure were more cooperative and trustful than those in the classroom (Ahmed \& Salas, 2013) and in the restaurant (Xygalatas, 2013). Finally, individuals were more willing to donate to a charity during Sundays which is the usual day when people attend religious services (Malhotra, 2010). In these similarly consistent findings on the influence of context primes in prosocial behavior, Xygalatas (2013) shared the same contention with other scholars suggesting that the communal salience of these religious contexts may have activated the norm for prosociality.

Religious word primes also facilitate prosocial behavior. For example, words such as "God" and "sacred" elicited more generosity in an economic game (Shariff \& Norenzayan, 2007). Words such as "faith" and "bless" also led to increased prosocial intentions (Pichon, Boccato, \& Saroglou, 2007). Unscrambling sentences which contain God-related concepts increase willingness to volunteer for environmental cause (Sasaki et al., 2011). Priming with religious words also reduced cheating (Randolph-Seng \& Nielsen, 2007), and increased donations 
(Hernandez \& Preston, 2010 as cited in Preston, Ritter, \& Hernandez, 2010). These religious priming studies indicate that activating religious representation through religion-related words may have semantically activated prosocial behaviors (Pichon et al., 2007; Shariff \& Norenzayan, 2007). However, Ritter and Preston (2013) contended that different religious word primes elicited different levels of prosocial behavior towards an ingroup or outgroup. Ingroup (as opposed to outgroup) refers to a group wherein an individual shares similarities with the members and these similarities may be based on kin, being friends, similar values, and beliefs among others (Triandis, 1994). Specifically, participants under "God" prime demonstrated more cooperation and less ingroup bias compared to those under "religion" prime (Preston \& Ritter, 2013). Together, these previous findings suggest that different word primes may also facilitate varying levels of prosocial behavior.

The findings of previous studies suggesting that different word primes elicit varying levels of prosocial behavior towards an ingroup or outgroup led to an investigation in the different word primes. Ritter and Preston (2013) suggested that there are different kinds of word primes which also entail distinct psychological functions and these are religious agents (e.g., God, angel), spiritual/abstract prime (e.g., divine, sacred), and institutional/concrete prime (e.g., ritual, scripture). The same authors contended that different kinds of word primes elicit different levels of prosocial behavior. Agent primes were facilitative of prosocial behavior towards both ingroup and outgroup (Ritter \& Preston, 2013) and this may explain why "God" prime led to less ingroup bias than "religion" prime (Preston \& Ritter, 2013). In the present study, "God" prime (agent prime) was used to measure its effect in volunteer time.

Looking closely, it is noticed that in most of the studies in both contextual and word primes, there was no priming method which utilized music as the medium for priming. With this, the present study utilized music as a priming method. Music has an influence in helping behavior (e.g., North, Tarrant, \& Hargreaves, 2004) and religion has been using music to express faith and to communicate with God (Laroche, 1992; Shiloah, 1997). It has been observable in Christianity and in the bible that music has been employed even in early times and it is reflected in the Psalms and canticles in which praise, worship, and bible passages were conveyed through songs. Moreover, the music prime is about "God" in which recent review on religious priming studies suggest that God prime (an agent prime; Ritter \& Preston, 2013) facilitates both helping the ingroup and outgroup (Preston \& Ritter, 2013). Thus, the present study utilized music about a watching God and its hypothesized influence in prosocial behavior specifically in increasing volunteer time for helping disaster survivors.

\section{Method}

\subsection{Research design}

The study focused on two independent groups experiment which utilized priming as the experimental manipulation. Priming is primarily used to activate prime-related thoughts without the explicit knowledge of the participant (Bargh \& Chartrand, 2000). It has been found to be effective in eliciting prime-related thoughts and behaviors (Dijksterhuis \& Bargh, 2001; Harris, Bargh, \& Brownell, 2009). Specifically, participants in the experimental condition received the "thought of a watching God" prime whereas the participants in control condition received the neutral prime.

\subsection{Participants}

A total of 296 college undergraduate students participated in the experiment. There were 152 males $(51.4 \%)$ and 144 females $(48.6 \%)$ with age ranging from 16 to 24 years old $(M=19.14$ years, $S D=2.1$ years $)$. Participants were recruited through the experimental psychology class. There were 142 (48\%) participants in the prime condition and $154(52 \%)$ in the non-prime condition. In terms of their self-rated religiosity, around 44 percent of them indicated that they were moderately religious and 56 percent as highly religious.

\subsection{Procedure}

College undergraduate students from the University of San Carlos, Cebu City were recruited through an experimental psychology class. Experiments to be conducted in these classes need to undergo ethics review with 
the assigned reviewers in the Psychology department. Because the experiment posed a minimal risk for the participants, the approval to conduct the experiment was given. During the actual experiment, participants filled up the informed consent and were randomly assigned in either experimental or control condition. Both the experimental and control conditions were administered (but separately) in the same classroom.

In the experimental condition, participants translated the song "God is watching you" by Leslie Phillips. The process was the same for the control condition except that the song was "Twinkle, twinkle, little star". Participants both listened to and read the song and were given time to finish the translation. Participants varied in their time for finishing the translation task. This translation task was already the priming. After the translation, experimenters instructed the participants to fill-up some documents in the desk located just outside the class room. While the participant was about to fill-up some documents, another student (also part of the experiment) approached the participant, requested a little time from the experimenter, and asked if he/she was willing to volunteer in helping recent disaster survivors. The participant then was given an invitation letter and asked to write his/her name, contact details, and number of hours in a week he/she was willing to allot for the volunteer work.

After filling up the invitation letter, the participant continued to fill up the demographic information for the experiment. The experimenter then conducted suspicion probe which include questions (a) "Please briefly speculate on what you think this study was about so far," and (b) "Has there been anything that you do not understand or find odd about this study so far?" (Shariff \& Norenzayan, 2007). There were no answers from these two questions that point to the true intention of the study. Debriefing was conducted and incentives were given. During the debriefing, they were also asked about how religious they viewed themselves and rate it through 1 (not religious), 2 (moderately religious), and 3 (highly religious).

\section{Results}

The aim of the present study was to test supernatural monitoring hypothesis, the influence of the thought of a watching God in prosocial behavior, specifically in the hours willing to devote for a volunteer work. It was hypothesized that participants primed with the thought of a watching God will devote more volunteer time compared to those who were not primed. Through a between-subjects experiment, two groups underwent either the priming (heard and translated a God-related song) or non-priming (not God-related song) condition. Dependent variable was measured through the number of hours the participant was willing to devote in a week for a volunteer work. An independent samples t-test was conducted to determine whether there was a significant difference between the primed and non-primed participant in terms of the time willing to volunteer (see table 1).

\section{Table 1}

Summary of result for independent samples t-test between prime \& non-prime condition of volunteer hours

\begin{tabular}{|c|c|c|c|c|c|c|c|c|}
\hline & \multicolumn{2}{|c|}{ Levene's test } & \multirow[b]{2}{*}{$\mathrm{t}$} & \multirow[b]{2}{*}{$d f$} & \multirow[b]{2}{*}{ Mean Diff. } & \multirow[b]{2}{*}{ SE } & \multicolumn{2}{|c|}{$95 \%$ CI of difference } \\
\hline & $\mathrm{F}$ & Sig. & & & & & Lower & Upper \\
\hline Equal variances assumed & .849 & .358 & $2.63 * *$ & 294 & .33 & .12 & .08 & .57 \\
\hline Equal variances not assumed & & & 2.62 & 285.8 & .33 & .12 & .08 & .57 \\
\hline
\end{tabular}

Levene's test showed that the variance in the two groups was equal $(F=.849, p=.358)$. With this, results showed that there was a significant difference $[t(294)=2.63, p<.01]$. Specifically, participants who were primed $(M=2.73, S D=1.11)$ volunteered more time (approximately 20 minutes) than those who were not primed $(M=2.40, S D=1.02)$. This supports the hypothesis that priming about God elicits prosocial behavior. However, the magnitude of the difference between the means was small (eta squared $=.023$ ).

\section{Discussion}

It has been suggested that one's thought about God facilitates prosocial behavior (Shariff \& Norenzayan, 
2007). A growing bulk of studies has found a link between religiosity and prosocial behavior (Saroglou, 2013). In terms of experimental studies, religious priming through words or context elicit prosocial behavior (for recent review, see Shariff, Willard, Andersen, \& Norenzayan, 2015). More interestingly, the present study used another medium for priming which is through a song. With this,the present study experimentally investigated the contention of supernatural monitoring hypothesis. Specifically, a between-groups experiment was employed to test the influence of religious priming through the song "God is watching you" in an individual's willingness to volunteer in terms of the number of hours to devote for the volunteer work in a week.

Results of the present study suggested that activating one's thought of a watching God increases prosocial behavior. This is consistent with the previous studies in religious priming (for review, see Ritter \& Preston, 2013 and Shariff et al., 2015). In this connection, result of the present study supports the supernatural monitoring hypothesis suggesting that the thought of a supernatural agent monitoring one's behavior facilitates prosocial behavior (Norenzayan \& Shariff, 2008). This thought may be viewed as a social surveillance (Gervais \& Norenzayan, 2012) and thus the individual needs to comply with what the supernatural agent (i.e., God) expects him/her to act in a social situation wherein he/she needs to act prosocially. This ability to think about what the supernatural agent also thinks (Norenzayan et al., 2014) facilitates helping not only one's ingroup but also the outgroup because the individual is motivated to avoid costly sanctions from both the supernatural agent and the community imposing the norm of religious helping (Johnson \& Bering, 2006). In a large society, failure to monitor and sanction people who violate the norms may have a significant impact into the society's social development (Dunbar, 2003; Henrich, 2006; Roes \& Raymond, 2003). Thus, the result of the present study may indicate that thinking about a watching God may serve to implicitly monitor the actions of an individual and in this case exhibit prosocial behavior to those needing help.

Moreover, the study provided further support to the contention that "God" prime, as a religious agent prime (Ritter \& Preston, 2013), facilitates prosocial behavior towards the outgroup (Preston \& Ritter, 2013). Agent primes activate the thought that supernatural agents are concerned with human morality (Ritter \& Preston, 2013); thus helping needs to be non-discriminatory and is targeted not only to significant and close others but also to strangers and unknown targets. As to institutional primes such as priming of religious practices, Ritter and Preston (2013) contended that these primes primarily activate concern for one's religion and thus the religious group in general which may partly explain why these institutional primes facilitate helping only the ingroup but not the outgroup. With this, the present study illustrates that the thought of a watching "God", an agent prime, elicits prosocial behavior towards those targets who need help but were not necessarily close to the individuals willing to volunteer.

It is noteworthy to mention that "God" as the religious prime may have made more salient among those who consider themselves religious the personal relevance of helping. When participants were asked about their level of religiosity, most of them considered themselves as religious. With this, the added personal relevance of the prime may have contributed more consistency to one's willingness to volunteer (e.g., Wheeler, DeMarree, \& Petty, 2007). Even in the context of charity giving, the personal relevance of the cause of charity giving contributes to more involvement (Sargeant \& Woodliffe, 2007). More importantly, engaging in prosocial behavior may contribute to feelings of joy (Andreoni, 1989; Batson \& Shaw, 1991) and has also been linked to activation of the brain's reward system (Harbaugh, Mayr, \& Burghart, 2007). Thus, eliciting from an individual his/her willingness to volunteer may not only benefit the recipient of help but may also benefit the individual himself. In the present study, eliciting help through priming may provide the same psychological benefits.

Furthermore, the present study extends religious priming literature in terms of the method for priming. Specifically, priming was conducted through listening to "God is watching you" song. Music facilitates helping (North et al., 2004). Religions in the different parts of the world and since ancient times use music as part of their religious practices (Laroche, 1992; Shiloah, 1997). Thus, it is noteworthy to consider priming through a song as an effective way of activating an individual's thought of a watching God. It can be that religious praise, and worship songs serve to prime the thought of a watching God which then facilitates prosocial behavior. This 
provides interesting insight to what Malhotra (2010) called Sunday effect. In Sunday effect, individuals were more generous to charity giving during Sundays than other days because, as the results of the present study indicate, they may have been primed with the thought of a watching God through the songs they have heard from attending religious services.

In general, the primary practical implication of the present study indicates that priming one's thought about God facilitates helping not only the significant others but even those non-significant others who need help. This not only benefits the recipient of the help but also the individual giving the help. It has been demonstrated in the present study that religious priming through a song also facilitates prosocial behavior. This may provide a practical use in the context of learning. For example, learning is best enhanced when students interact and help each other (Lalley \& Miller, 2007). With this, prosociality-related songs to start a class may be helpful in setting up an atmosphere conducive for learning.

The present study has some limitations that may be addressed in further studies. Theoretically, supernatural monitoring hypothesis is not the only contention that explains the results of the present study. Other theories may also complement in explaining the result (e.g, Alcorta \& Sosis, 2005; Crespi \& Summers, 2014; Graham \& Haidt, 2010). Recent study also found that overlapping perception of religiosity and spirituality may also influence willingness to help (Batara, 2015). Second, it has also been suggested in other studies (e.g., Bering et al., 2005) that increased reputational concern may explain why religious priming facilitates prosocial behavior. Thus, further experiments may look into and measure reputational concern's role in the link between religiosity and prosocial behavior. Despite these limitations, the study was able to provide empirical evidence that priming through religious song has an influence in prosocial behavior.

\section{Conclusion}

People do not just go to church and give their tithes. People practice their religion and help those in need. Practice of religion in general is viewed as a way that reinforces helping behavior (Skinner, 1969). However, studies investigating the link between religiosity and helping behavior have consistently found a weak association (Saroglou, 2006, 2013). A lot of theories emerged in explaining the underlying mechanisms and the necessary conditions for the religion-prosociality link to occur. One of these emerging theories is the idea of a watching God influencing the role of religiosity in prosocial behavior (e.g., Shariff \& Norenzayan, 2007). Through an experiment, the present study found that priming through religious song facilitates prosocial behavior. Religion has an influence in the different areas on an individual's life (e.g., Cohen, 2015). The present study indicates that religion is one of the factors that has an influence in an individual's prosocial behavior. Thinking about an omniscient and omnipresent God facilitates volunteering and in general prosocial behavior.

\section{References}

Ahmed, A. M. (2009). Are religious people more prosocial? A quasi-experimental study with Madrasah pupils in a rural community in India. Journal for the Scientific Study of Religion, 48, 368-374. http://dx.doi.org/10.1111/j.1468-5906.2009.01452.x

Ahmed, A., \& Salas, O. (2013). Religious context and prosociality: An experimental study from Valparaíso, Chile. Journal for the Scientific Study of Religion, 52(3), 627-637. http://dx.doi.org/10.1111/jssr.12045

Alcorta, C. S., \& Sosis, R. (2005). Ritual, emotion, and sacred symbols. Human nature, 16(4), 323-359. http://dx.doi.org/10.1007/s12110-005-1014-3

Allport, G. W. (1966). The religious context of prejudice. Journal for the Scientific Study of Religion, 5, 447-457. http://dx.doi.org/10.2307/1384172

Andreoni, J. (1989). Giving with impure altruism: applications to charity and Ricardian equivalence. The Journal of Political Economy, 1447-1458. http://dx.doi.org/10.1086/261662

Bargh, J. A., \& Chartrand, T. L. (2000). The mind in the middle. In H. Reis \& C. Judd (Eds.), Handbook of research methods in social psychology (pp. 253-285). New York: Cambridge University Press. 
Batara, J. B. L. (2015). Overlap of religiosity and spirituality among Filipinos and its implications towards religious prosociality. International Journal of Research Studies in Psychology, 4(3), 3-21. http://dx.doi.org/10.5861/ijrsp.2015.1090

Batson, C. D. (1976). Religion as prosocial: Agent or double agent? Journal for the Scientific Study of Religion, 15, 29-45. http://dx.doi.org/10.2307/1384312

Batson, C. D. (1990). Good samaritans...or priests and levites? Using William James as a guide in the study of religious prosocial motivation. Personality and Social Psychology Bulletin, 16, 758-768. http://dx.doi.org/10.1177/0146167290164015

Batson, C. D., \& Shaw, L. L. (1991). Evidence for altruism: Toward a pluralism of prosocial motives. Psychological Inquiry, 2(2), 107-122. http://dx.doi.org/10.1207/s15327965pli0202_1

Bering, J. M., \& Johnson, D. D. P. (2005). 'Oh Lord, you hear my thoughts from afar': Recursiveness in the cognitive evolution of supernatural agency. Journal of Cognition and Culture, 5, 118-142. http://dx.doi.org/10.1163/1568537054068679

Bering, J. M., McLeod, K., \& Shackelford, T. K. (2005). Reasoning about dead agents reveals possible adaptive trends. Human Nature, 16(4), 360-381. http://dx.doi.org/10.1007/s12110-005-1015-2

Cohen, A. B. (2015). Religion's profound influences on psychology morality, intergroup relations, self-construal, and enculturation. Current Directions in Psychological Science, 24(1), 77-82. http://dx.doi.org/10.1177/0963721414553265

Crespi, B., \& Summers, K. (2014). Inclusive fitness theory for the evolution of religion. Animal Behaviour, 92, 313-323. http://dx.doi.org/10.1016/j.anbehav.2014.02.013

Dijksterhuis, A., \& Bargh, J. A. (2001). The perception-behavior expressway: Automatic effects of social perception on social behavior. Advances in Experimental Social Psychology, 33, 1-40. http://dx.doi.org/10.1016/S0065-2601(01)80003-4

Dunbar, R. I. M. (2003). The social brain: Mind, language, and society in evolutionary perspective. Annual Review of Anthropology, 32, 163-181. http://dx.doi.org/10.1146/annurev.anthro.32.061002.093158

Galen, L. W. (2012). Does religious belief promote prosociality? A critical examination. Psychological Bulletin, 138(5), 876-906. http://dx.doi.org/10.1037/a0028251

Gervais, W. M., \& Norenzayan, A. (2012). Like a camera in the sky? Thinking about God increases public self-awareness and socially desirable responding. Journal of Experimental Social Psychology, 48, 298-302. http://dx.doi.org/10.1016/j.jesp.2011.09.006

Graham, J., \& Haidt, J. (2010). Beyond beliefs: Religions bind individuals into moral communities. Personality and Social Psychology Review, 14(1), 140-150. http://dx.doi.org/10.1177/1088868309353415

Harbaugh, W. T., Mayr, U., \& Burghart, D. R. (2007). Neural responses to taxation and voluntary giving reveal motives for charitable donations. Science, 316, 1622-1625. http://dx.doi.org/10.1126/science.1140738

Harris, J. L., Bargh, J. A., \& Brownell, K. D. (2009). Priming effects of television food advertising on eating behavior. Health Psychology, 28(4), 404-413. http://dx.doi.org/10.1037/a0014399

Henrich, J. (2006). Cooperation, punishment, and the evolution of human institutions. Science, 312, 60-61. http://dx.doi.org/10.1126/science.1126398

Hill, P. C., Pargament, K. I., Hood, R. W. Jr., McCullough, M. E., Swyers, J. P., Larson, D. B., \& Zinnbauer, B. J. (2000). Conceptualizing religion and spirituality: Points of commonality, points of departure. Journal for the Theory of Social Behaviour, 30, 51-77. http://dx.doi.org/10.1111/1468-5914.00119

Johnson, D. D., \& Bering, J. M. (2006). Hand of God, mind of man: Punishment and cognition in the evolution of cooperation. Evolutionary Psychology, 4(1), 219-233. http://dx.doi.org/10.1177/147470490600400119

Lalley, J. P., \& Miller, R. H. (2007). The learning pyramid: Does it point teachers in the right direction? Education, 128(1), 64-79.

LaPierre, L. L. (1994). A model for describing spirituality. Journal of Religion and Health, 33, 153-161. http://dx.doi.org/10.1007/BF02354535

Laroche, M. (1992). Music, dance, religion. Callaloo, 15(3), 797-810. http://dx.doi.org/10.2307/2932022

Lewis, V. A., MacGregor, C. A., \& Putnam, R. D. (2013). Religion, networks, and neighborliness: The impact of 
religious social networks on civic engagement. Social Science Research, 42(2), 331-346. http://dx.doi.org/10.1016/j.ssresearch.2012.09.011

Lincoln, R., Morrissey, C. A., \& Mundey, P. (2008). Religious giving: A literature review. Report for the John Templeton Foundation Generosity Planning Project. Retrieved from http://generosityresearch.nd.edu/assets/20447/religious_giving_final.pdf

Malhotra, D. (2010). "Sunday Effect" on pro-social behavior. Judgment and Decision Making, 5(2), 138-143.

Norenzayan, A., \& Shariff, A. F. (2008). The origin and evolution of religious prosociality. Science, 322, 58-62. http://dx.doi.org/10.1126/science.1158757

Norenzayan, A., Shariff, A. F., Gervais, W. M., Willard, A. K., McNamara, R. A., Slingerland, E., \& Henrich, J. (2014). The cultural evolution of prosocial religions. Behavioral and Brain Sciences, 1-86. Retrieved from http://eslingerland.sites.olt.ubc.ca/files/2014/12/Norenzayan_etal_BBS_preprint.pdf http://dx.doi.org/10.1017/S0140525X14001356

North, A. C., Tarrant, M., \& Hargreaves, D. J. (2004). The effects of music on helping behavior: A field study. Environment and Behavior, 36(2), 266-275. http://dx.doi.org/10.1177/0013916503256263

Pargament, K. I. (1997). The psychology of religion and coping: Theory, research, practice. New York: Guilford Press.

Pargament, K. I. (1999). The psychology of religion and spirituality? Yes and no. International Journal for the Psychology of Religion, 9, 3-16. http://dx.doi.org/10.1207/s15327582ijpr0901_2

Piazza, J., Bering, J. M., \& Ingram, G. (2011). Princess Alice is watching you: Children's belief in an invisible person inhibits cheating. Journal of Experimental Child Psychology, 109, 311-320. http://dx.doi.org/10.1016/j.jecp.2011.02.003

Pichon, I., \& Saroglou, V. (2009). Religion and helping: Impact of target, thinking styles and just-world beliefs. Archive for the Psychology of Religion, 31, 215-236. http://dx.doi.org/10.1163/157361209X424466

Pichon, I., Boccato, G., \& Saroglou, V. (2007). Nonconscious influences of religion on prosociality: A priming study. European Journal of Social Psychology, 37, 1032-1045. http://dx.doi.org/10.1002/ejsp.416

Preston, J. L., \& Ritter, R. S. (2013). Different effects of religion and God on prosociality with the ingroup and outgroup. Personality and Social Psychology Bulletin, 39(1), 1471-1483. http://dx.doi.org/10.1177/0146167213499937

Preston, J. L., Ritter, R. S., \& Hernandez, I. J. (2010). Principles of religious prosociality: A review and reformulation. Social and Personality Psychology Compass, 4(8), 574-590. http://dx.doi.org/10.1111/j.1751-9004.2010.00286.x

Preston, J. L., Salomon, E., \& Ritter, R. S. (2013). Religious prosociality: Personal, cognitive, and social factors. In V. Saroglou (Ed.), Religion, Personality, and Social Behavior (pp. 149-169). New York: Psychology Press.

Purzycki, B. G., \& Sosis, R. (2009). The religious system as adaptive: Cognitive flexibility, public displays, and acceptance. In The biological evolution of religious mind and behavior (pp. 243-256). Springer Berlin Heidelberg. http://dx.doi.org/10.1007/978-3-642-00128-4_17

Randolph-Seng, B., \& Nielsen, M. E. (2007). Honesty: One effect of primed religious representations. The International Journal for the Psychology of Religion, 17(4), 303-315. http://dx.doi.org/10.1080/10508610701572812

Ritter, R. S., \& Preston, J. L. (2013). Representations of religious words: Insights for religious priming research. Journal for the Scientific Study of Religion, 52(3), 494-507. http://dx.doi.org/10.1111/jssr.12042

Roes, F. L., \& Raymond, M. (2003). Belief in moralizing gods. Evolution and Human Behavior, 24, $126-135$. http://dx.doi.org/10.1016/S1090-5138(02)00134-4

Ruffle, B., \& Sosis, R. (2010). Do religious contexts elicit more trust and altruism? An experiment on Facebook. Discussion Paper No. 10-02, Department of Economics: Ben-Gurion University. Retrieved from http://www.ec.bgu.ac.il/monaster/admin/papers/1002.pdf http://dx.doi.org/10.2139/ssrn.1566123

Sargeant, A., \& Woodliffe, L. (2007). Gift giving: an interdisciplinary review. International Journal of Nonprofit and Voluntary Sector Marketing, 12(4), 275-307. http://dx.doi.org/10.1002/nvsm.308

Saroglou, V. (2006). Religion's role in prosocial behavior: Myth or reality? Psychology of Religion Newsletter: 
American Psychological Association Division, 36, 31, 1-8.

Saroglou, V. (2012). Is religion not prosocial at all? Comment on Galen (2012). Psychological Bulletin, 138(5), 907-912. http://dx.doi.org/10.1037/a0028927

Saroglou, V. (2013). Religion, spirituality, and altruism. In K. I. Pargament, J. J. Exline, \& Jones, J. W. (Eds.), APA handbook of psychology, religion, and spirituality: Context, theory, and research. APA handbooks in psychology (Vol. 1, pp. 439-457). Washington, DC: American Psychological Association. http://dx.doi.org/10.1037/14045-024

Saroglou, V., Pichon, I., Trompette, L., Verschueren, M., \& Dernelle, R. (2005). Prosocial behavior and religion: New evidence based on projective measures and peer ratings. Journal for the Scientific Study of Religion, 44, 323-348. http://dx.doi.org/10.1111/j.1468-5906.2005.00289.x

Sasaki, J. Y., Kim, H. S., Mojaverian, T., Kelley, L. D., Park, I. Y., \& Janušonis, S. (2011). Religion priming differentially increases prosocial behavior among variants of the dopamine D4 receptor (DRD4) gene. Social Cognitive and Affective Neuroscience, 8, 209-215. http://dx.doi.org/10.1093/scan/nsr089

Sedikides, C. (2010). Why does religiosity persist? Personality and Social Psychology Review, 14(1), 3-6. http://dx.doi.org/10.1177/1088868309352323

Shariff, A. F., Norenzayan, A., \& Henrich, J. (2009). The birth of high Gods: How the cultural evolution of supernatural policing agents influenced the emergence of complex, cooperative human societies, paving the way for civilization. In M. Schaller, A. Norenzayan, S. Heine, T. Yamagishi, \& T. Kameda (Eds.), Evolution, culture, and the human mind (pp. 119-136). New York: Psychology Press.

Shariff, A. F., Willard, A. K., Andersen, T., \& Norenzayan, A. (2015). Religious Priming: A meta-Analysis with a focus on prosociality. Personality and Social Psychology Review, 1-22. http://dx.doi.org/10.1177/1088868314568811

Shariff, A. F., \& Norenzayan, A. (2007). God is watching you: Priming God concepts increases prosocial behavior in an anonymous economic game. Psychological Science, 18, 803-809. http://dx.doi.org/10.1111/j.1467-9280.2007.01983.x

Shiloah, A. (1997). Music and religion in Islam. Acta Musicologica, 69(2), 143-155. http://dx.doi.org/10.2307/932653

Skinner, B. F. (1969). An operant analysis of problem-solving. In Skinner, B. F., Contingencies of reinforcement: a theoretical analysis (pp. 133-157). Appleton-Century-Crofts: USA.

Triandis, H. C. (1994). Culture and social behavior. New York: McGraw-Hill.

Underwood, L. G. (2002). The human experience of compassionate love: Conceptual mapping and data from selected studies. In S. Post, L. G. Underwood, J. P. Schloss, \& W. B. Hurlbut (Eds.), Altruism and altruistic love: Science, philosophy and religion in dialogue (pp. 72-88). New York, NY: Oxford University Press. http://dx.doi.org/10.1093/acprof:oso/9780195143584.003.0009

Wheeler, S. C., DeMarree, K. G., \& Petty, R. E. (2007). Understanding the role of the self in prime-to-behavior effects: The active-self account. Personality and Social Psychology Review, 11(3), 234-261. http://dx.doi.org/10.1177/1088868307302223

Wulff, D. M. (1997). Psychology of religion: Classic and contemporary (2nd ed.). New York: Wiley \& Sons.

Xygalatas, D. (2013). Effects of religious setting on cooperative behavior: A case study from Mauritius. Religion, Brain \& Behavior, 3(2), 91-102. http://dx.doi.org/10.1080/2153599X.2012.724547

Zinnbauer, B. J., Pargament, K. I., \& Scott, A. B. (1999). The emerging meanings of religiousness and spirituality: Problems and prospects. Journal of Personality, 67, 889-919.

http://dx.doi.org/10.1111/1467-6494.00077

Zinnbauer, B. J., Pargament, K., Cole, B., Rye, M. S., Butter, E. M., Belavich,T. G., Hipp, K. M., Scott, A. B., \& Kadar, J. L. (1997). Religion and spirituality: Unfuzzying the fuzzy. Journal for the Scientific Study of Religion, 36, 549-564. http://dx.doi.org/10.2307/1387689

Zuckerman, M. (2005). Psychobiology of personality (Second edition, revised and updated). New York: Cambridge University Press. http://dx.doi.org/10.1017/CBO9780511813733 